\title{
Development of Interactive Water Cycle Materials for Fifth Graders
}

\author{
Faridah Istianah ${ }^{1, *}$ Siska N. Sari ${ }^{1}$ Ika Rahmawati $^{1}$ Suryanti $^{1}$ \\ ${ }^{1}$ Universitas Negeri Surabaya \\ Corresponding author.Email: ikarahmaika13@gmail.com
}

\begin{abstract}
This research aims to develop a valid, practical, and compelling multimedia interactive learning of water cycle material to improve student learning outcomes. The type of research used is development research by Borg and Gall, which researchers limit to 7 steps due to the Covid-19 pandemic. The research subjects used eight students of class V UPT SDN 191. The data obtained were analyzed descriptively quantitatively in validation results, user response questionnaires, and Posttest-Pretest results. Validity was obtained based on media and material validation results with a percentage of $89.58 \%$ and $87.5 \%$ (very valid). The practicality of the media was obtained based on the results of student and teacher questionnaire responses with percentages of $98.75 \%$ and $100 \%$ (efficient). While the effectiveness is obtained based on the average pretest score of 78 and posttest score of 85 , it can be seen that the average value of posttest> Pretest with the percentage of complete learning outcomes is $87.5 \%$. It can be concluded that interactive multimedia learning of water cycle material is very valid, practical, and effective in science learning of water cycle material.
\end{abstract}

Keywords: development, interactive learning multimedia, water cycle.

\section{INTRODUCTION}

Education is defined as an effort to promote the nation's quality of life and create a generation of superior quality. Education is a learning activity to create students who actively develop their talents and skills [1].

The development of technology and knowledge in the 21 st century is increasingly demanding the creation of an update in learning activities. The behaviour of educators teachers demanded openness and technology literacy to establish innovative learning activities. Factors that can affect the success of the learning process are facilities and infrastructure. Students' learning facilities must be in line with increasingly renewable technological developments, namely by utilizing technological advances into learning media that students participate in and following the characteristics of learning in the 2013 curriculum. In determining the media, learning materials, teaching objectives, character, and level of thinking of students [2].

Science P: What Knowledge of Nature (IPA) is lessons are integrated into the curriculum of 2013. Learning science aims to improve the knowledge and talent of the students in understanding natural phenomena by giving directly to the student experience [3]. Science learning must be carried out following the characteristics of science material related to natural phenomena to be declared successful if all learning objectives have been achieved. Implementation of science learning in elementary schools is expected that students can understand basic science process skills, so students need to learn about science process skills by adjusting to the cognitive stage development of elementary school students [4]. One of the science subjects taught in class V of Elementary School is the water cycle. The water cycle originates from the land and sea surfaces that evaporate into the atmosphere and undergo various processes until it turns into clouds, then returns to the earth as rain [5]. So that in delivering the material, alternative media are needed to replace the original object so that the delivery of water cycle material can run effectively and make it easier for students to understand the material.

The observations and interviews with teachers at a public elementary school, on October 7, 2020, show that the supporting facilities for teaching and learning activities at the school are quite complete such as the availability of student books, blackboards, book corners, computers and Projector LCD. However, in the learning process, the teacher has not used it optimally to support the completeness of the media. Science teaching activities in class of the public elementary school on the material of the water cycle tends to be passive, and some students feel quickly tired and sleepy. The cause is learning that focuses solely on the teacher and the lack of teachers' creativity in media selection so that just using textbooks and media 
images that are glued to student books. The process of teaching the monotony early media usage limitations result in the low spirit of student learning so that students do not can absorb stamp duty to the maximum, and result in low levels of student understanding of the water cycle of matter.

Based on these problems, researchers will develop alternative media for teaching and learning activities by utilizing computers in interactive multimedia learning of the water cycle. With the development of increasingly sophisticated technology, information can be easily obtained by utilizing computer technology because most of the entire community (children to adults) can operate computers in the current era. In elementary schools, computers have also been provided to support learning. Therefore, according to researchers, interactive multimedia learning of the water cycle will be an effective alternative media for science content. Interactive learning multimedia is defined as a teaching program in a combination of images, audio, text, animation, etc. Using a computer and users can interact directly with the program to achieve learning objectives [6].

In making interactive learning multimedia, researchers used Adobe Flash CS6 software. They packaged it in a particular form consisting of attractive images, animations, writing, and colours and equipped with a simulation of the water cycle process as a substitute for the original object to make it easier for students to understand the process of the water cycle so that can improve students' understanding of the water cycle material. The design of developing interactive learning multimedia is adapted to the character and development of students as targets for the use of interactive learning multimedia to be developed, as according to Piaget which states that the level of thinking of fifth-grade elementary school students is still in the concrete operational stage [7]. Through this interactive learning multimedia, students can learn while playing in learning and discovering water cycle material directly to increase students' curiosity.

According to Munir, the use of interactive multimedia has advantages, including: ( 1 ) the learning process becomes active, creative, and fun; (2) assisting educators in developing creativity and learning innovation; (3) writing, images, videos, animations can be combined into one media unit; (4) able to increase students' interest in learning; (5) able to describe material that is difficult to explain using simple media [8]. In this interactive multimedia learning, the water cycle material is also accompanied by a video of the water cycle experiment so that students can directly conduct a water cycle experiment by following the steps contained in the media video and equipped with an evaluation so that they can evaluate students' knowledge in understanding the material.

There has been a success in previous research using interactive learning multimedia, namely research conducted by Windah et al. [9]. The study results stated that interactive multimedia was feasible and successful in increasing student motivation and learning outcomes. Differences her with this study is the material, the location of the study, the research subjects. The material used in this study is a simple aircraft material, while the water cycle material is used in this study. Then research by Noviyah states that interactive multimedia based on auto play is feasible and effective to use and increases student learning outcomes [10]. Differences to research this are the subject matter, subject and location of the study, and software media creation. In the previous study, the material used is meme care of a neighbourhood and use the software Autoplay, but in this study, the material used is the water cycle and the help of software Adobe Flash CS6.

The success of previous research using interactive learning multimedia was also carried out by Fandu et al. [11]. In this study, it was stated that interactive multimedia based on the approach of the set was declared feasible to use and increased students' critical thinking skills. The difference with this research is the research location, the research subject. Previous research aims to improve students' critical thinking skills while in this study to improve student learning outcomes.

Based on the background description above, interactive multimedia learning is expected to be able to assist teachers in the teaching process as a creative and innovative learning medium by following the development of renewable technology. So that this is realized in development research with the title "Development of Interactive Learning Multimedia for Elementary School Class V Water Cycle Materials". The objectives of this research are: (1) to describe the validity of interactive multimedia learning materials for the fifth grade of elementary school water cycle; (2) to describe the practicality of interactive multimedia learning materials for the fifth grade of elementary school water cycle; (3) to describe the effectiveness of interactive learning multimedia on water cycle material for class $\mathrm{V}$ Elementary School.

The limitations in this development research are: (1) this interactive learning multimedia focuses on the content of the science lesson on water cycle material in K13, Theme 8, Sub-theme 1, Learning 2; (2) interactive multimedia learning of the water cycle operated using a computer; (3) interactive multimedia learning materials on the water cycle were developed for fifth-grade elementary school students.

\section{METHODS}

The type of research used by researchers in the research and development in terms of a procedure used for me to create a product and assess the efficiency of the products mentioned [12]. This research aims to create a new product or provide improvements to the previous product to foster student learning motivation. In this research, the product is interactive multimedia learning material on the water cycle. 
According to Sugiyono, the Borg and Gall development research model has ten development steps [12]. Researchers limit this development research model to 7 steps of development. This is due to limited costs, time and the existence of the Covid-19 pandemic Researchers cannot conduct large-scale research. The modification of the research steps can be described through the following chart:

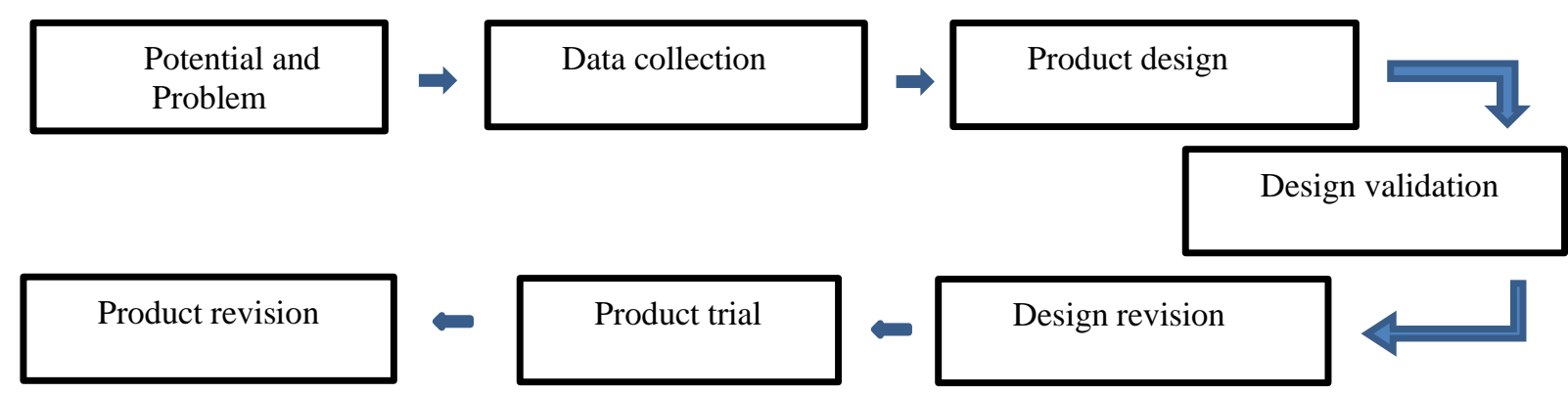

Figure 1 Modified Borg and Gall Research Step

The first $\mathrm{L}$ number is to determine the potential and the problem. Researchers conducted observations and interviews with teachers of UPT SDN 191 Gresik on October 27, 2020. It can be seen the potential that exists in the school, namely supporting facilities for teaching and learning activities that are pretty complete such as the availability of student books, book corners, blackboards, computers and LCD projectors. While the problems found by researchers are in science learning, the water cycle material tends to be passive, and some students feel bored and sleepy quickly, the cause is learning that only focuses on the teacher, and the teacher's lack of creativity in choosing media so that only textbooks and picture media are glued. On the student book. The monotonous teaching and learning process makes students unable to absorb material optimally and causes a low level of student understanding of the water cycle material. Accordingly, multimedia interactive learning is an alternative learning medium to foster motivation to learn and yield improvement in student learning.

The second step is data collection. In this case, the researcher conducts a literature study on student books, teacher books, and the internet. The initial design was obtained based on the thematic book class V revision 2017 on Theme 8, Subtheme 1, Learning two on Basic Competencies: 3.8 Analyzing the water cycle and its impact on events on earth and the survival of living things. With the scope of discussion regarding the material: (1) understanding of the water cycle ; (2) the process of the water cycle; (3) human activities that affect the water cycle ; (4) efforts to preserve water. It also obtained data that teachers and students of grade V Elementary School were able to operate computers.

In the third step, the researchers designed the design and concept/content on the interactive multimedia learning material for the water cycle, which was packaged in a particular form - in this case, designing interactive learning multimedia products with the help of Adobe Flash CS6 software. Media product designs are made complete with specifications and packaged in storyboard form (script draft).
The fourth step is design validation, which is the stage of assigning value to the product design that researchers have developed to know its effectiveness [12]. So that it can find the advantages and disadvantages of media design before being tested, the interactive learning multimedia will be validated by two validators, namely media experts and material experts, with criteria including:

After the validation of the product design, the fifth step is then carried out to improve the product design based on criticism and suggestions from the validator. These efforts were made to create higher quality learning media before being tested on several students.

The sixth step is product testing. The media that has been revised according to the validator's direction will be tested limited to class $\mathrm{V}$ of the school students around the researcher's house. The trial was carried out by providing interactive multimedia learning materials for the water cycle to students. After using interactive multimedia learning, students and teachers were given a questionnaire response to the use of the media. Researchers also distributed pretest and posttest to determine the effectiveness of the media.

The final step is the revision of the final product. This is because of the Covid-19 virus pandemic, and it is not possible to carry out large-scale trials. The data from the limited trial results in the form of questionnaires from student and teacher responses related to the use of interactive multimedia learning materials for the water cycle were used for revision materials in improving and perfecting the developed media.

The trial subjects for interactive multimedia learning water cycle materials were eight students of class V UPT SDN 191 Gresik, who lived around the researcher's house. Due to the covid-19 pandemic, it was not possible to carry out large-scale trials in elementary schools. In this development, research gets two types of data is qualitative data based on suggestions and feedback from the validator and quantitative data obtained based on: (1) the validation data media from validator media and materials; (2) the use of questionnaire data, namely 
student and teacher responses; (3) student test result data in the form of pretest and posttest.

The data from the validation results are used to determine the validity of interactive learning multimedia products measured through media expert validation sheets and material in the form of a questionnaire concerning the Likert scale, including $4=$ very good; $3=\operatorname{good} ; 2=$ not good; $1=$ very bad. The assessment criteria in the media validation sheet include (1) appearance, (2) media content, (3) use. At the same time, the assessment criteria in the material validation sheet include: (1) the suitability of the material with competence; (2) the content of the material; (3) language. As for the media and material validation instruments used in this study, as follows:

Table 1. Media Validation Sheet Grid

\begin{tabular}{|c|c|c|c|c|}
\hline No & Criteria & Indicator & Number of Items & Item Number \\
\hline \multirow[t]{3}{*}{1} & \multirow[t]{3}{*}{ Appearance } & Background selection & 1 & 1 \\
\hline & & Back sound selection & 1 & 2 \\
\hline & & Display quality & 1 & 3 \\
\hline \multirow{4}{*}{2} & \multirow{4}{*}{ Media Content } & Font size and selection & 2 & 4.5 \\
\hline & & Colour selection & 1 & 6 \\
\hline & & Image selection & 2 & 7,8 \\
\hline & & Animation Selection & 1 & 9 \\
\hline \multirow{3}{*}{3} & \multirow{3}{*}{ Use } & Ease of use of media & 1 & 10 \\
\hline & & Use of navigation keys & 1 & 11 \\
\hline & & Instructions for use & 1 & 12 \\
\hline
\end{tabular}

Table 2. Material Validation Sheet Grid

\begin{tabular}{c|l|l|c|c|}
\hline No & \multicolumn{1}{|c|}{ Criteria } & \multicolumn{1}{c|}{ Indicator } & Number of Items & Item Number \\
\hline 1 & $\begin{array}{l}\text { Conformity of } \\
\text { Material with } \\
\text { Competence }\end{array}$ & $\begin{array}{l}\text { The suitability of the material with K Basic } \\
\text { Competence, Indicators }\end{array}$ & 2 & 1,2 \\
\hline 2 & Contents & Suitability of material content & 5 & $3,4,5,6,7$ \\
\hline 3 & language & Language compatibility with EYD & 2 & 8.9 \\
\cline { 3 - 5 } & & Providing convenience for students & 1 & 10 \\
\hline
\end{tabular}

Data analysis of the results of the media and material validation assessment can be known by using the calculation formula:

$$
P S A=\frac{\sum \text { alternative answer selected every aspect }}{\sum \text { alternative answer ideal every aspect }} \times 100 \%
$$

From the calculation, the reference level of the validity of the developed media is obtained. The following is the percentage of media validity levels:

Table 3. Media Validity Level Percentage

\begin{tabular}{c|c|}
\hline Percentage & Information \\
\hline $75 \% \leq$ PSA $100 \%$ & Very Valid \\
\hline $50 \% \leq$ PSA $74 \%$ & Valid \\
\hline
\end{tabular}

\begin{tabular}{c|c|}
\hline $25 \% \leq$ PSA 49\% & Less Valid \\
\hline PSA 24\% & Invalid \\
\hline
\end{tabular}

Furthermore, the data from the questionnaire responses of teachers and students related to interactive multimedia learning were used to determine the practicality of interactive multimedia learning. The teacher and student response questionnaire include several indicators such as (1) the quality of the media 
display, (2) media presentation, (3) media benefits. The teacher response questionnaire sheet is based on the Likert scale, but the student response questionnaire sheet is based on the Guttman scale "Yes" and "No".

The student and teacher response questionnaire instruments used in this study are as follows:

Table 4. Student Response Questionnaire Grid

\begin{tabular}{c|l|c|c|}
\hline No & \multicolumn{1}{|c|}{ Indicator } & $\begin{array}{c}\text { Number } \\
\text { of Items }\end{array}$ & $\begin{array}{c}\text { Item } \\
\text { Number }\end{array}$ \\
\hline 1 & Media display quality & 5 & $1,2,3,4,5$ \\
\hline 2 & Media presentation & 3 & $6,7,8$ \\
\hline 3 & Media benefits & 2 & 9,10 \\
\hline
\end{tabular}

Table 5. Teacher Response Questionnaire Grid

\begin{tabular}{c|l|c|c|}
\hline No & \multicolumn{1}{|c|}{ Indicator } & $\begin{array}{c}\text { Number of } \\
\text { Items }\end{array}$ & $\begin{array}{c}\text { Item } \\
\text { Number }\end{array}$ \\
\hline 1 & Media display quality & 5 & $\begin{array}{c}1,2,3 \\
4,5\end{array}$ \\
\hline 2 & Media presentation & 3 & $6,7,8$ \\
\hline 3 & Media benefits & 2 & 9.10 \\
\hline
\end{tabular}

Data analysis of the results of the questionnaire responses of teachers and students can be known by using the calculation formula:

$$
P S A=\frac{\sum \text { alternative answer selected every aspect }}{\sum \text { alternative answer ideal every aspect }} \times 100 \%
$$

From the calculation, we get a reference level to the practitioners of the developed media. The following is the percentage of media validity levels:

Table 6. Media Practicality Level Percentage

\begin{tabular}{l|l|}
\hline \multicolumn{1}{|c|}{ Percentage } & \multicolumn{1}{c|}{ Information } \\
\hline $0 \%-20 \%$ & Not Practical \\
\hline $21 \%-40 \%$ & Less Practical \\
\hline $41 \%-60 \%$ & Practical enough \\
\hline $61 \%-80 \%$ & Practical \\
\hline $81 \%-100 \%$ & Very Practical \\
\hline
\end{tabular}

Pretest and posttest data were used to determine the effectiveness of multimedia interactive learning that is calculated using the following formula:

$$
\bar{x}=\frac{\sum x}{n}
$$

The test results of the pretest and posttest were used to determine the percentage of the mastery learning by using a calculation formula:

$$
\begin{aligned}
& P=\frac{\text { Number of students who scored } \geq 75}{\text { Total number of students }} x \\
& 100 \%
\end{aligned}
$$

The following is the percentage of complete learning:
Table 7. Mastery Learning

\begin{tabular}{ll}
\hline \multicolumn{1}{c}{ Percentage } & \multicolumn{1}{c}{ Information } \\
\hline $0 \%-20 \%$ & Not good \\
$21 \%-40 \%$ & Not good \\
$41 \%-60 \%$ & Pretty good \\
$61 \%-80 \%$ & Well \\
$81 \%-100 \%$ & Very good \\
\hline
\end{tabular}

[14]

Interactive learning multimedia products became effective when the value of the average posttest $>$ pretest den gan percentage of mastery learning $\geq 61$.

\section{RESULTS AND DISCUSSION}

\subsection{Research Results}

The research results conducted by this researcher are interactive multimedia learning of water cycle material in class V Elementary School in a particular form. They can be operated using a computer/laptop.

In the early stages, the result of the observations and interviews with teachers in a public elementary school (SDN 191), Gresik had found significant problems in learning activities in the science material water cycle where students tend to be passive. Some students feel quickly tired and sleepy. The cause is learning that only focuses on the teacher and the teacher's lack of creativity in selecting media so that they only use textbooks and picture media glued to student books. The monotonous teaching and learning process makes students unable to 
absorb material optimally and causes low levels of understanding about the water cycle material.

Through interviews with teachers of a public elementary school (UPT SDN 191), data obtained as a potential associated with supporting facilities, teaching and learning activities that are complete enough as (1) the availability of books students and teachers to use the curriculum book, 2013; (2) there is a book corner in each class; (3) the availability of a blackboard; (4) availability of computers; and (5) LCD projector.

Furthermore, the researchers conducted a literature study on thematic books (students and teachers) and the internet to collect information. Based on the results of the study, it was obtained that the initial literature draft based on books thematic revision of the $2017 \mathrm{~V}$ class at eight themes, Subtheme 1, Lesson 2 with the Basic Competence: 3.8 analyzing the water cycle and its impact on the events of the earth and the survival of living beings. With the scope of discussion regarding the material: (1) understanding of the water cycle; (2) the process of the water cycle; (3) human activities that affect the water cycle; (4) efforts to preserve water. Se avg data showed that teachers and Elementary School fifth grade students could operate a computer.

At the stage of making the media design, researchers made flowcharts to facilitate making media. They made storyboards to make more specific and detailed designs related to interactive multimedia learning products for water cycle materials. The following is a flowchart of interactive multimedia learning material on the water cycle, namely:

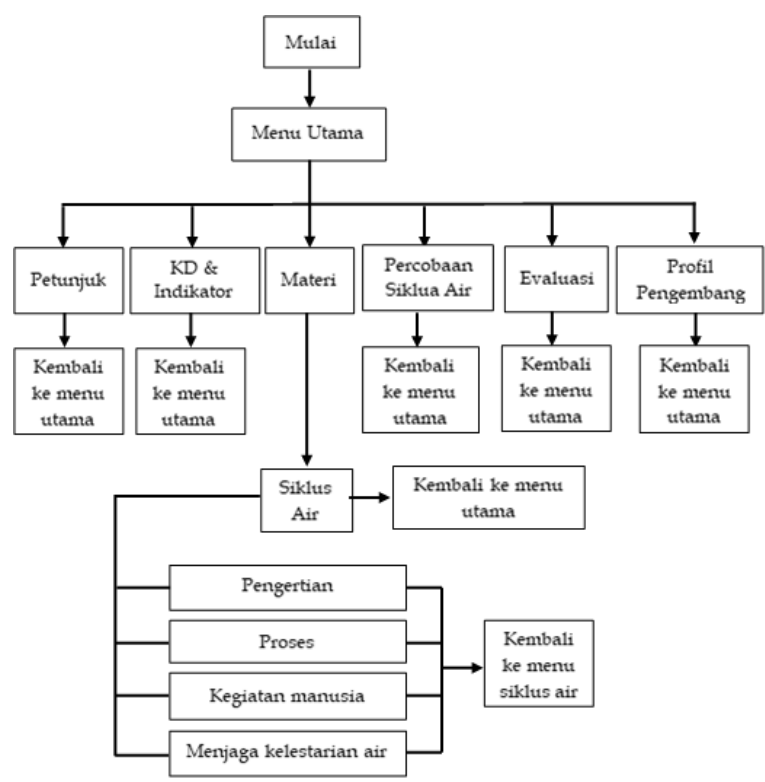

Figure 2. Interactive Multimedia Water Cycle Material Flowchart

The flowchart results are then displayed in more detail on the storyboard. The next stage is the creation of interactive multimedia learning materials for the water cycle in a particular format and operated on a computer. The stage of making water cycle learning multimedia using Adobe Flash CS6 Software with product displays, including:

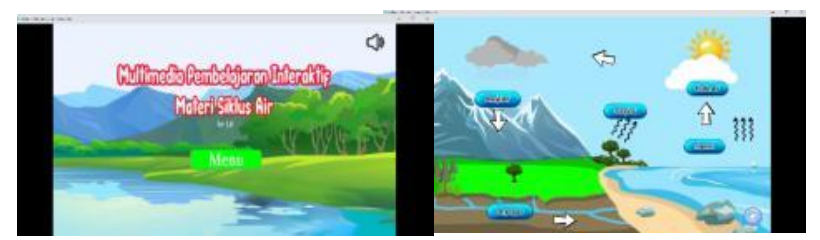

Figure 3. Interactive Multimedia Water Cycle Material

Next, the media validation stage was carried out by the media validator and interactive multimedia learning on the water cycle material. An expert validator assessed the validation of the water cycle interactive multimedia learning media. This event was held on March 21, 2021, to fill out a validation questionnaire with 12 indicators and provide a checklist $(\checkmark)$ with a 1-4 Likert scale.

The formula calculation above obtained a percentage of $89.58 \%$, which means it has been declared very valid. However, according to suggestions from the validator, there are slight revisions, such as the evaluation font for the answers to be equated with the questions and the colour of the answer boxes changed for the better.

While the validation of material experts on interactive multimedia learning of the water cycle was assessed by an expert validator from a science lecturer, this activity was held on March 22, 2021, to fill out a form validation questionnaire with ten indicators and provide a checklist ( $\checkmark$ ) with a 1-4 Likert scale.

From the formula calculation above, it was obtained a percentage of $87.5 \%$, which means it has been declared very valid. However, according to suggestions from the validator, there are slight revisions, such as adding a mini-lab to invite students to do activities to find a concept and practice questions not only cover categories C1-C3 only.

After the product validation stage, the researcher then made product improvements based on suggestions from the validator to improve product quality. The following are the results of media improvements, including:

After the product validation and revision process on interactive multimedia learning of water cycle material, the next stage is to conduct a limited product trial to 8 class V students of UPT SDN 191 Gresik. They live around the researcher's house. Due to the covid-19 virus pandemic, it is impossible to carry out wide-scale trials in elementary school. The trial was carried out on March 25, 2021, by distributing questionnaires for student and teacher user responses to determine the practicality of interactive learning multimedia.

Sheet student response questionnaire consists of 10 indicators to provide a checklist ( $\checkmark$ ) with Guttman scale 
"Yes" and "No". The following is the acquisition of data from the student response questionnaires:
Based on the result of the student response questionnaire, a score of 43 points will be obtained, which will then be calculated using the formula according to Sugiyono [13]:

$$
\begin{gathered}
P S A=\frac{\sum \text { alternative answer selected every aspect }}{\sum \text { alternative answer ideal every aspect }} \times 100 \% \\
P S A=\frac{79}{80} \times 100 \% \\
P S A=98,75 \%
\end{gathered}
$$

From the calculation of the formula above, obtained a percentage of $98.75 \%$, which means it has been declared very practical and feasible to use.

Meanwhile, the practicality of interactive multimedia learning on water cycle materials is also known based on the questionnaire responses from the fifth-grade teacher of the school. The teacher's response questionnaire consists of 10 indicators to provide a checklist $(\checkmark)$ with a 1-4 Likert scale. The following is the acquisition of data from the teacher's response questionnaire:

Based on the results of the teacher response questionnaire, a score of 40 points will be obtained, which will then be calculated using the formula according to Sugiyono [13]:

$$
\begin{gathered}
P S A=\frac{\sum \text { alternative answer selected every aspect }}{\sum \text { alternative answer ideal every aspect }} \times 100 \% \\
P S A=\frac{40}{40} \times 100 \% \\
P S A=100 \%
\end{gathered}
$$

The formula calculation above obtained a percentage of $100 \%$, which means it has been declared very practical without any revision.

Furthermore, the pretest and posttest were given to 8 class V UPT SDN 191 Gresik, who lived around the researcher's house. The results of the pretest and posttest were used to determine the effectiveness of interactive multimedia learning on water cycle materials, and the following results were obtained:

The data from the pretest and posttest were then calculated using the following formula:

Pretest Score:

$$
\begin{aligned}
& \bar{x}=\frac{\sum x}{n} \\
& \bar{x}=\frac{480}{8}=78
\end{aligned}
$$

Posttest Score:

$$
\begin{aligned}
& \bar{x}=\frac{\sum x}{n} \\
& \bar{x}=\frac{680}{85}=85
\end{aligned}
$$

Based on the calculation of the formula above, the pretest value is 78 , and the posttest value is 85 , then calculate the percentage of mastery learning by calculating the formula:

$$
\begin{aligned}
& P=\frac{\text { Number of students who scored } \geq 75}{\text { Total number of students }} \times 100 \% \\
& P=\frac{7}{8} \times 100 \% \\
& P=87,5 \%
\end{aligned}
$$

Then it is known that the value of the average posttest> pretest $t$ with a percentage of $87.5 \%$ completeness study were categorized as excellent.
Therefore, interactive multimedia learning materials for the water cycle are declared to be effective in increasing learning outcomes.

\subsection{Discussion}

A multimedia product for interactive learning of water cycle materials operated using a computer packaged in a particular form. According to Munir, interactive multimedia combines several elements such as sound, images, writing, and video animation into a systematic unit that can provide benefits to users [8]. The development of interactive multimedia learning on water cycle materials using the Borg and Gall research model according to Sugiyono, which researchers limit to 7 steps of development, this is due to limited costs, time and the existence of the covid-19 pandemic, researchers cannot research on a large scale [12]. This research aims to determine the validity, practicality, and effectiveness of interactive multimedia learning with water cycle material.

The choice of interactive learning multimedia as a medium for teaching and learning activities is because the material presented in interactive learning multimedia is packaged attractively by combining writing, pictures, music, video and animation. These interactive learning multimedia is equipped with several menus such as instructions, KD and Indicators, materials, water cycle animations, water cycle experiment videos, evaluations, and developer profiles. According to Munir, the use of interactive multimedia has advantages, including: (1) The learning process becomes active, creative and fun; (2) Assist educators in developing creativity by making teaching innovations; (3) Writing, pictures, sound, animated videos can be combined into a medium to help achieve learning objectives; (4) Increase students' interest 
in learning to take part in learning so that learning objectives can be achieved; (5) Able to describe material that is difficult to explain using only simple media; (6) Forming independent students in learning [8].

Through this interactive multimedia learning, students can learn while playing in learning and discovering water cycle material directly to increase students' curiosity. This is following the opinion of Wibawanto, some of the benefits of learning media include: (1) the presentation of messages is not only in the form of verbality or writing ; (2) able to control the limitations of the senses, space, and time; (3) growing motivation to learn, creating interaction between students and the environment and creating students who can learn independently according to their talents and interests; (4) raises the same perception and equates the experiences of students [16].

Based on the results of product validation, which aims to produce decent media and find out the advantages and disadvantages of the media before being tested, it gets a score with a percentage of $89.58 \%$ in media validation. It can be said that interactive multimedia learning material for the water cycle is suitable for use with a valid category. Riduwan argues that the media is expressed very validly if scored with vulnerable PSA $\leq 75 \% \leq$ $100 \%$ [14]. In the media validator, researchers get suggestions for improving the media. The evaluation font for the answers is the same as the questions, and the colour of the answer box is changed for the better. Based on this, researchers fix the media by justifying the font size on the question and the answer options and changing the background colour on the answers to become more attractive.

Material experts also carry out the validation process. On material validation, it gets a score with a percentage of $87.5 \%$. It can be said that interactive multimedia learning of water cycle material is feasible to use with a very valid category. Riduwan argues that media expressed very valid if scored with vulnerable PSA $\leq$ $75 \% \leq 100 \%$ [14]. Researchers get suggestions for media improvement in the material validator, namely adding a mini-lab to invite students to do activities to find a concept and practice questions by not only covering categories C1-C3 only. Therefore, the researchers made improvements by adding a water cycle experiment menu equipped with a water cycle experiment video and replacing four questions with category $\mathrm{C} 4$. In addition, the results of previous research conducted by Dewi showed validation results by material and media experts with values of $90.8 \%$ and $91 \%$, respectively [17].

Furthermore, the practicality of interactive multimedia learning on water cycle materials can be obtained based on filling out questionnaires for student and teacher responses related to media use. In this study, the researchers used 8 grade five students of the public elementary school who lived around the researcher's house due to the covid-19 virus pandemic. The questionnaire results get a percentage of $98.75 \%$, including the very practical category. Moreover, the teacher's response questionnaire got a $100 \%$ percentage result, including the practical category. The statement follows Riduwan argument that the media is expressed efficient use if scored with a vulnerable $81 \%-100 \%$ [14]. In line with the opinion of Sadiman et al., the practicality of the media can be seen from the user's interest and the ease of using the media to maximize the achievement of the learning objectives [18].

Nieveen et al. stated that the learning outcomes data could be seen from the effectiveness of a media [19]. The effectiveness of interactive multimedia learning on water cycle materials was obtained based on the results of the pretest and protest given to 8 fifth grade students of UPT SDN 191 Gresik. Pretest sheets are given to students before using interactive learning multimedia. Then posttest sheets are given after students use interactive learning multimedia. The pretest-posttest sheet contains 20 multiple choice questions with the same weight. The result is that the average pretest score is 78 , and the posttest average is 85 . From these acquisitions, it can be seen that the average value of posttest $>$ Pretest with a learning completeness percentage of $87.5 \%$ because there is one student whose score is below 75. Following the opinion of Riduwan stated that students' learning mastery is declared very good if they get a score with a vulnerable $81 \%-100 \%$ [14]. According to Nugraheni, the use of multimedia interactive learning can influence the improvement of learning outcomes in grades posttest. This is because multimedia interactive learning comes with some menu items such as manual, material, video experiment water cycle, evaluation, and other feedback [20]. Therefore, interactive multimedia learning materials on the water cycle are declared feasible, and there is an increase in learning outcomes.

\section{CONCLUSION AND SUGGESTION}

\subsection{Conclusion}

Based on the results of the discussion of research conducted by researchers regarding the development of interactive multimedia learning materials for class $\mathrm{V}$ Elementary School, it can be concluded that: (1) The results of the validity of the media are obtained based on the results of the validation by the media and material validators. Media validation obtained a percentage of $89.58 \%$ with a valid category, and material validation obtained a percentage of $87.5 \%$ with a good category; (2) $\mathrm{H}$ acyl practicality media obtained based on the result of filling the questionnaire responses students and teachers regarding the use of media. The results of the student questionnaire obtained a percentage of $98.75 \%$, including the convenient category. Moreover, the teacher's response questionnaire results obtained a percentage of $100 \%$, including the convenient category ; (3) The effectiveness of interactive multimedia learning on water cycle materials can be determined based on the average pretest score of 78 posttest score of 85 . From these 
acquisitions, it can be seen that the average value of Posttest $>$ Pretest with a learning completeness percentage of $87.5 \%$. Therefore, the interactive multimedia learning material on the water cycle is declared feasible and can improve learning outcomes.

\subsection{Suggestion}

Based on the research results on the development of interactive multimedia learning materials for the fifth grade of the elementary school water cycle. Suggestions related to media development can be given, namely: (1) The developed media can be used as an alternative and reference in developing media for different materials; (2) The media still needs to be tested on a large scale in elementary schools to prove the effectiveness of using interactive multimedia learning in the classroom; (3) The lack of interactive multimedia learning on water cycle material can be a motivation to develop similar media with better quality, such as providing precise voice quality dubbing to make it easier to understand the content of the material.

\section{REFERENCES}

[1] Ministry of National Education. 2003. Law of the Republic of Indonesia Number 20 of 2003 concerning the National Education System. Jakarta: Ministry of National Education.

[2] N. Sudjana, A. Rivai, Teaching Media: Their Use and Making, The New Light of Algensido, 2015.

[3] U. Samatowa, Elementary School Science Learning, PT Index, 2011.

[4] F. N. Kumala, Primary School Science Learning, Poor, Edide Infographics, 2016.

[5] S. Sosrodarsono, K. Takeda, Hydrology for Irrigation, Paramita's Parad, 2003.

[6] H. D. Surjono, Multimedia Pembelajaran Interaktif, Kraft and Developing, UNY Press, 2017.

[7] A. Budiningsih, Characteristics of Students as Learning Bases, FIP, 2005.

[8] Munir, Multimedia; Concepts \& Applications in Education, Alphabeta, 2012.

[9] W. Octafiana, et al., development of interactive multimedia content pes at a wat simple for elementary school students, Journal of Educational Communication, 2018, pp. 168-175.

[10] Noviyah. 2016. Development of Interactive multimedia-based Autoplay to Improve Learning Outcomes P No Mata lesson IPS Material Maintain Environmental Class III MI Y aspuri M reeds. (Online) https://etheses.uinmalang.ac.id/id/eprint/9605 [accessed December $25,2020]$
[11] F. Z. Firdaus, et al, Development of SETS-based interactive multimedia to improve critical thinking ability of elementary school students, Basicedu Journal, 2020, pp. 681-689.

[12] Sugiyono. Educational Research Methods (Quantitative, Qualitative, and R\&D Approaches) Alphabeta, 2015.

[13] Sugiyono., Quantitative, Qualitative, and R\&D Research Methods, Alphabeta, 2016.

[14] Riduwan, Measurement Scale of Research Variables, Alphabeta, 2013.

[15] S. Arikunto, Fundamentals of Educational Evaluation, Earth Literacy, 2012.

[16] W. Wibawanto, Design and Programming of Interactive Learning Multimedia, Publisher Ulet Creative Smart, 2017.

[17] N. R. Dewi, Development of interactive multimedia for information services about interpersonal communication for students at SMPN 2 Sumbergempol Tulungangung", Unpublished Thesis, 2017.

[18] A. S. Sadiman et al, Educational Media, PT Rajagrafindo Persada, 2014.

[19] Nieveen, Formative Evaluation in Educational Design Research, Kluwer Academic Publishers, 2007.

[20] D. Rahmawaty, F. Rachmadiarti, Development of flash interactive multimedia on the interaction of living things with the environment to improve learning outcomes of class VII junior high school students, Pensa E-Journal: Science Education, 2019, pp. 317-327. 